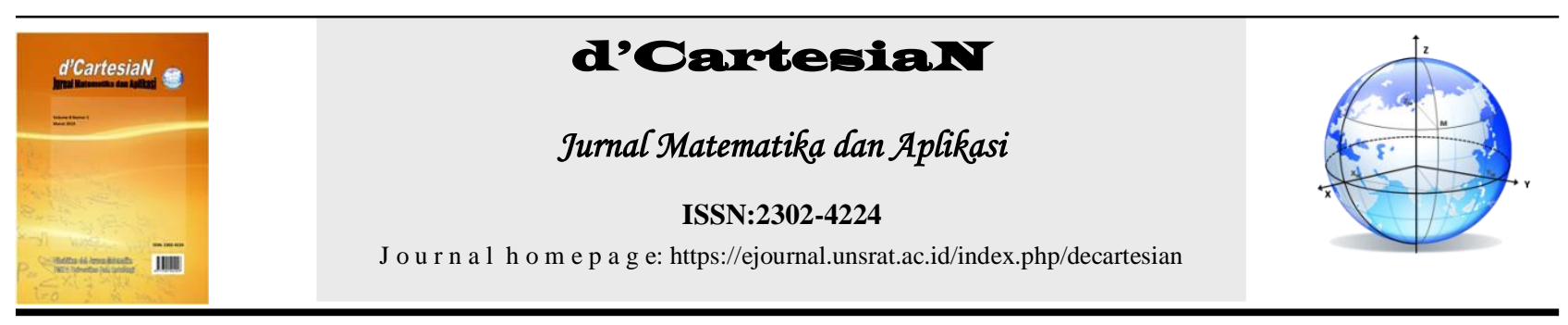

\title{
Plot Multivariate Desa dan Kelurahan di Kota Kotamobagu Berdasarkan Indikator Sosial Ekonomi
}

\author{
Siti Regina O. Malah ${ }^{1}$, Charles E. Mongi ${ }^{1}$, Hanny A.H. Komalig ${ }^{1^{*}}$
}

${ }^{1}$ Jurusan Matematika-Fakultas Matematika dan Ilmu Pengetahuan Alam-Universitas Sam Ratulangi Manado, Indonesia

${ }^{*}$ Corressponding author : hanoyo7@yahoo.com

\section{A B S T R A K}

Tujuan penelitian ini untuk mengetahui desa dan kelurahan yang mempunyai tingkat kemiripan kesejahteraan berdasarkan variabel sosial ekonomi yang ada dengan menggunakan Plot Multivariate dan untuk mengetahui variabel sosial ekonomi yang mempengaruhi kemiripan tingkat kesejahteraan ,dengan menggunakan metode Analisis Komponen Utama (AKU) dan Analisis Faktor. Hasil yang di dapatkan bahwa pada analasis komponen utamadigunakan 3 kompenen utamadengan nilai kumulatif 65,936\% dengan 4 kelompok tingkat kesejahteraan, dan pada analisis faktor variabel yang mempengaruhi titik tingkat kemiripan kesejahteraan adalah variabel Jumlah Lembaga Adat $\left(X_{4}\right)$, Laju Pertumbuhan Penduduk Per Tahun $\left(X_{6}\right)$, Jumlah Rumah Tangga (RT) per Kepala Keluarga $\left(X_{8}\right)$, Jumlah Taman Kanak-kanak $\left(X_{9}\right)$, Jumlah Sekolah Dasar $\left(X_{10}\right)$, Jumlah Tempat Peribadatan $\left(X_{13}\right)$, Jumlah PBB Bruto $\left(X_{16}\right)$ pada $K U_{1}$, variabel Jumlah RT per Desa atau Kelurahan $\left(X_{2}\right)$, Jumlah Penduduk Tahun $2017\left(X_{5}\right)$, Jumlah Total Penduduk $\left(X_{7}\right)$ pada $K U_{2}$, dan variabel Jumlah Industri Lainnya $\left(X_{15}\right)$,Jumlah PBB Neto $\left(X_{17}\right)$ pada $K U_{3}$.
\end{abstract}

\section{INFO ARTIKEL}

Diterima : 28 Februari 2019

Diterima setelah revisi : 22 Maret 2019

Tersedia online : 31 Maret 2019

\section{Kata Kunci:}

Sosial Ekonomi

Analisis Komponen Utama

Analisis Faktor

\section{PENDAHULUAN}

Upaya peningkatan kualitas Sumber Daya Manusia (SDM) dan pemanfaatan Sumber Daya Alam (SDA) secara optimal merupakan langkah untuk meningkatkan sosial ekonomi di suatu wilayah atau daerah yang bertujuan untuk mensejahterakan masyarakat. Di Indonesia sendiri berdasarkan data Badan Pusat Statistik (BPS) pada tahun 2017 pertumbuhan sosial ekonomi di Indonesia meningkat $5,07 \%$ dari tahun yang sebelumnya. Sosial ekonomi sendiri adalah salah satu faktor yang sangat mempengaruhi tingkat kesejahteraan suatu daerah, [2] menyatakan pusat perhatian dalam memandang pembangunan sosial ekonomi Indonesia adalah manusia, budaya adalah penjelmaan manusia dalam sikapnya berhadapan dengan lingkungan alam dan sosialnya. Perbedaan tingkat pembangunan manusia wilayah akan berdampak pada perbedaan tingkat kesejahteraan daerah sehingga ketimpangan pembangunan manusia pun semakin melebar.

Untuk memahami ketimpangan pembangunan di suatu daerah, sebaiknya dilakukan dalam suatu kurun waktu. Hal ini dilakukan agar mengetahui apakah ketimpangan pembangunan semakin mengecil atau semakin membesar, dalam kaitannya dengan pembangunan manusia. Oleh karena itu, pemerintah perlu mengamati data pertumbuhan sosial ekonomi disetiap wilayah dimana dalam ilmu statistika untuk memberikan informasi pertumbuhan sosial ekonomi tersebut salah satu cara yang digunakan yaitu dengan Analisis Peubah Ganda (APG). Ada dua metode yang digunakan dalam APG yaitu Analisis Komponen utama
(AKU) dan Analisis Faktor, AKU merupakan Teknik statistik yang digunakan untuk menjelaskan struktur variansi-kovarians dari sekumpulan variabel melalui beberapa variabel baru ini saling bebas dan merupakan kombinasi linear dari variabel asal. Analisis Komponen Utama pada dasarnya bertujuan untuk menyederhanakan peubah yang diamati dengan cara menyusutkan (mereduksi) dimensinya. Hal ini dilakukan dengan jalan menghilangkan korelasi di antara peubah melalui transformasi peubah asal ke peubah baru yang tidak saling berkorelasi. Sedangkan Analisis Faktor merupakan kajian tentang saling ketergantungan antara variabel-variabel, dengan tujuan untuk menemukan himpunan variabel-variabel baru, yang lebih sedikit jumlahnya dari pada variabelvariabel semula itu yang merupakan faktor-faktor persekutuan [13].

Pada penelitian [5], dibuat untuk menggambarkan kondisi sosial ekonomi masyarakat serta melakukan analisis korelasi komponen sosial ekonomi masyarakat yang memanfaatkan ekosistem di mangrove teluk kotania, dengan metode analisis yang digunakan berupa Analisis Komponen Utama dengan pendekatan Participatory Rural Apprasial (PRA), dengan hasil analisis yang menggambarkan bahwa tingkat Pendidikan responden memiliki hubungan dengan keputusan yang diambil dalam pemanfaatan ekosistem mangrove.

[9] melakukan analisis jumlah spesies tumbuhan obat yang digunakan berdasarkan pengaruh faktor sosial ekonomi, lingkungan, dan faktor geografis berdasarkan tingkat keterpencilan menggunakan 
Analisis Komponen Utama dan hasil penelitian yang menunjukan bahwa komponen infrastruktur dan ekonomi dan jumlah penduduk lulus Sekolah Dasar (SD) mempengaruhi jumlah jenis tumbuhan obat yang digunakan. Dan sebelumnya juga [1] dengan tujuan untuk menggabungkan dua gugus data peubah ganda dengan menggunakan Analisis Komponen Utama .

Berdasarkan uraian di atas, maka dalam penelitian ini dengan menggunakan Analisis Komponen Utama (AKU) dan Analisis faktor untuk mengetahui desa dan kelurahan mana saja yang mempunyai indikator atau variabel berdasarkan sosial ekonomi yang mirip di Kota Kotamobagu dan variabel apa saja yang mempengaruhi kemiripan, dengan data sekunder yang didapatkan dari Badan Pusat Statistik (BPS).

\section{Sosial Ekonomi}

Pembangunan harus dipahami sebagai suatu proses yang multidimensional, yang melibatkan segenap pengorganisasian dan peninjauan kembali atas sistem-sistem ekonomi dan sosial secara keseluruhan. Selain peningkatan pendapatan dan output, proses pembangunan itu juga berkenaan dengan serangkaian perubahan yang bersifat mendasar atas strukturstruktur kelembagaan, sosial, dan administrasi, sikapsikap masyarakat dan bahkan seringkali juga merambah adat-istiadat, kebiasaan, dan sistem kepercayaan yang hidup dalam masyarakat yang bersangkutan [14].

Menurut [3] kata sosial ekonomi mengandung pengertian sebagai sesuatu yang non moneter sifatnya yang bertalian dengan kualitas kehidupan insani. Sedangkan ekonomi dijelaskan sebagai lawan dari pengertian sosial yaitu dilibatkan kaitannya dengan uang. Dengan demikian kondisi sosial ekonomi berdasarkan pengertian di atas merupakan suatu kondisi yang terkait secara moneter dan non moneter. Kondisi sosial ekonomi keluarga didasarkan pada pendapatan keluarga, tingkat pendidikan orang tua, pendapatan orang tua dan status sosial di dalam masyarakat seperti, hubungan dengan masyarakat, asosiasi dalam kelompok masyarakat, dan persepsi masyarakat atas keluarga [4].

\section{Analisis Multivariat}

Analisis multivariat atau Analisis Peubah Ganda adalah Teknik-teknik analisis statistika yang memperlakukan sekelompok variabel yang saling berkorelasi sebagai satu system, dengan memperhitungkan korelasi antar variabel-variabel tersebut [13].

\subsubsection{Analisis Komponen Utama (AKU)}

Analisis Komponen Utama (AKU) dipelopori oleh Karl Pearson pada tahun 1901 untuk peubah nonstokastik, AKU adalah teknik statistik yang dapat digunakan untuk menjelaskan struktur variansikovariansi dari sekumpulan variabel baru di mana variabel baru ini saling bebas, dan merupakan kombinasi linier dari variabel asal.

AKU terkonsentrasi pada penjelasan struktur variansi dan kovariansi melalui suatu kobinasi linear variabel-variabel asal, dengan tujuan utama melakukan reduksi data dan membuat interpretasi. AKU lebih baik digunakan jika variabel-variabel asal saling berkorelasi [7]. Analisis Komponen Utama digunakan untuk menjelaskan struktur matriks varians kovarians dari suatu set variabel melalui kombinasi linier dari variabel-variabel tersebut. Secara umum komponen utama dapat berguna untuk reduksi dan interpretasi variabel-variabel.

Misalkan saja terdapat $p$ buah variabel yang terdiri atas $n$ buah objek. Misalkan pula bahwa dari $p$ buah variabel tersebut dibuat sebanyak $k$ buah komponen utama (dengan $k \leq p$ ) yang merupakan kombinasi linier atas $p$ buah variabel tersebut. $k$ komponen utama tersebut dapat menggantikan $p$ buah variabel yang membentuknya tanpa kehilangan banyak informasi mengenai keseluruhan variabel. Umumnya analisis komponen utama merupakan analisis intermediate yang berarti hasil komponen utama dapat digunakan untuk analisis selanjutnya.

Menurut [7], dalam bentuk matematis, katakan saja bahwa $Y$ merupakan kombinasi linier dari variabel-variabel $X_{1}, X_{2}, \ldots, X_{P}$ yang dapat dinyatakan sebagai :

$$
Y=W_{1} X_{1}+W_{2} X_{2}+\ldots,+W_{p} X_{P}
$$

Dengan :

$W_{i}$ adalah bobot atau koefisien untuk variabel ke $i$

$X_{i}$ adalah variabel ke $i$

$Y$ adalah kombinasi linier dari variabel $X$

Menurut [7], secara prinsip pembentukan komponen utama merupakan pembentukan kombinasi linier dari variabel-variabel yang diamati. Dalam analisis komponen utama ditentukan suatu metode untuk mendapatkan nilai-nilai koefisien atau bobot dari kombinasi linier variabel-variabel pembentuknya dengan ketentuan sebagai berikut

- Ada sebanyak $p$ komponen utama, yaitu sebanyak variabel yang diamati dan setiap komponen utama adalah kombinasi linier dari variabel-variabel tersebut

- $\quad$ Setiap komponen utama saling ortogonal (tegak lurus) dan saling bebas.

- Komponen utama dibentuk berdasarkan urutan varians dari yang terbesar hingga yang terkecil, dalam arti sebagai berikut:

* komponen utama pertama $\left(K U_{1}\right)$ merupakan kombinasi linier dari seluruh variabel yang diamati dan memiliki varians terbesar

* komponen utama kedua $\left(K U_{2}\right)$ merupakan kombinasi linier dari seluruh variabel yang diamati yang bersifat ortogonal terhadap $K U_{1}$ dan memiliki varians kedua terbesar

* komponen utama ketiga $\left(K U_{3}\right)$ merupakan kombinasi linier dari seluruh variabel yang diamati yang bersifat ortogonal baik terhadap $K U_{1}$ maupun $\mathrm{KU}_{2}$, dan memiliki varians ketiga terbesar $\vdots$

* komponen utama ke $p \quad\left(K U_{p}\right)$ merupakan kombinasi linier dari seluruh variabel yang diamati yang bersifat ortogonal terhadap $K U_{1}$, $K U_{2}, \ldots, K U_{(p-1)}$ dan memiliki varians yang terkecil.

Untuk mendapatkan koefisien komponen utama secara bersamaan dapat menggunakan salah satu cara berikut ini :

- dekomposisi eigen value dan eigen vector dari matriks korelasi atau kovarians dari variabelvariabel yang diamati. Dalam hal ini eigen value merupakan varians setiap komponen utamanya dan eigen vector merupakan koefisien-koefisien komponen utamanya.

- dekomposisi nilai singular dari matriks data yang berukuran $n \times p$. 
Interpretasi dari komponen utama adalah bahwa komponen utama tersebut merupakan suatu sistem sumbu baru dalam ruang vektor berdimensi banyak peubah yang diamati. Melalui komponen utama salibsalib sumbu tersebut telah diubah skalanya dan dirotasi hingga memiliki sifat varians yang terurut semakin kecil dan orthogonal.

Penetapan banyaknya komponen utama untuk dapat ditafsirkan dengan baik dapat dilihat dari beberapa metode yaitu:

- Proporsi keragaman kumulatif dari komponen utama, menurut [8], banyaknya komponen utama yang dipilih sudah cukup memadai apabila komponen utama tersebut mempunyai presentase keragaman kumulatif tidak kurang dari $60 \%$ total keragaman data.

- Nilai Eigen (eigenvalue),Pemilihan komponen utama yang digunakan, didasarkan pada eigenvalue. Aturan yang digambarkan pada bagian ini khusus digunakan untuk matriks korelasi, meskipun dapat digunakan juga untuk beberapa jenis matriks kovarians.

Ide dibalik aturan bahwa jika elemen $x$ adalah independen, maka komponen utama sama dengan variabel asli dengan semua memiliki unit varians pada kasus matriks korelasi. Sehingga setiap komponen utama dengan varians kurang dari 1 mengandung sedikit informasi dari salah satu variabel asli jadi tidak dapat dipertahankan.

\section{Analisis Faktor}

Analisis faktor adalah kajian tentang saling ketergantungan antara variabel variabel, dengan tujuan untuk menemukan himpunan variabel-variabel baru, yang lebih sedikit jumlahnya dari pada variabel semula, dan yang menunjukkan yang mana di antara variabelvariabel semula tersebut yang merupakan faktor-faktor persekutuan [13].

Analisis faktor merupakan salah satu metode statistik yang dapat dipergunakan untuk menemukan hubungan antar sejumlah variabel yang bebas satu sama lain, sehingga dapat dibuat satu atau beberapa kumpulan variabel saja [11].

\section{METODE PENELITIAN}

\subsection{Waktu dan Tempat Penelitian}

Penelitian ini dilaksanakan selama bulan November 2018 sampai April 2019. Sumber data yang diambil adalah data sekunder yang diambil di Badan Pusat Statistik (BPS) Kota Kotamobagu, pengolahan data dilakukan di Laboratorium Statistika di Jurusan Matematika Fakultas Matematika dan Ilmu Pengetahuan Alam Universitas Sam Ratulangi Manado.

\subsection{Sumber Data}

Data yang digunakan dalam penelitian ini adalah data sekunder yaitu data social ekonomi yang didapatkan dari Badan Pusat Statistik (BPS) tahun 2017. Data yang diambil adalah data sosial ekonomi Kotamobagu, Kecamatan Kotamobagu Barat, Kecamatan Kotamobagu Selatan, Kecamatan Kotamobagu Utara, dan Kecamatan Kotamobagu Timur.

\subsection{Variabel Penelitian}

17 variabel ini diambil berdasarkan indicator kesejahteraan rakyat menurut Badan Pusat Statistik:

$X_{1}$ : Luas desa

$X_{2}$ : Jumlah RT per kelurahan atau desa

$X_{3}$ : Tipe desa

$X_{4}$ : Jumlah lembaga adat

$X_{5}$ : Jumlah penduduk tahun 2017

$X_{6}$ : Laju pertumbuhan penduduk pertahun (\%)

$X_{7}$ : Jumlah total penduduk

$X_{8}$ : Jumlah Rumah Tangga (RT) per kepala keluarga

$X_{9}$ : Jumlah Taman Kanak-Kanak (TK)

$X_{10}$ : Jumlah Sekolah Dasar (SD)

$X_{11}$ : Jumlah Sekolah Menengah Pertama (SMP)

$X_{12}$ : Jumlah Puskesmas

$X_{13}$ : Jumlah Tempat Peribadatan

$X_{14}$ : Jumlah Industri makanan

$X_{15}$ : Jumlah Industri Lainnya

$X_{16}$ : Jumlah PBB bruto

$X_{17}$ : Jumlah PBB neto

\subsection{Tahapan Analisis Data}

Teknik analisis yang digunakan dalam mengaplikasikan model Analisis Komponen utama dan Analisis Faktor pada penelitian ini yaitu menggunakan perangkat lunak komputer yaitu Microsoft Office Excel, Minitab 17 dan IBM SPSS, dengan langkah-langkah tahapan penelitian sebagai berikut :

1. Analisis Korelasi

Data dilakukan pengujian dengan menggunakan analisis korelasi pearson dimana untuk melihat besar kecilnya hubungan dari tiap variabel. Jika terdapat korelasi maka dilakukan Analisis Komponen utama (AKU) untuk dapat melanjutkan ke tahap Analisis Faktor.

2. Analisis Komponen Utama (AKU)

Karena data asal memiliki korelasi maka dapat dilakukan AKU untuk menentukan jumlah dan bentuk persamaan komponen utama. Hasil AKU akan dijadikan dasar untuk menentukan jumlah faktor yang akan di Analisis Faktor

3. Membuat Plot Multivariate

untuk mengetahui desa dan kelurahan mana yang mempunyai kemiripan dengan desa dan kelurahan yang lainya berdasarkan variabelvariabel yang digunakan

4. Analisis Faktor

Hasil dari Komponen utama dijadikan data analisis untuk dapat mengetahui faktor-faktor apa saja yang mempengaruhi kemiripan antar desa dan kelurahan

\section{HASIL DAN PEMBAHASAN 3.1. Analisis Korelasi}

Dari 33 kelurahan dan desa di 5 kecamatan kota kotamobagu yang terdiri dari 17 variabel $\left(X_{1}, X_{2}, X_{3}, X_{4}, X_{5}, X_{6}, X_{7}, X_{8}, X_{9}, X_{10}, X_{11}, X_{12}, X_{13}, X_{14}, X_{15}\right.$, $X_{16}, X_{17}$ ), akan dilakukan analisis korelasi Pearson antar variabel untuk mengukur keeratan hubungan antar variabel, dimana hipotesisnya :

$$
\begin{aligned}
& H_{0}: \text { Tidak ada Korelasi antar Variabel }\left(r_{i j}=0\right) \\
& H_{1}: \text { Ada korelasi antar variabel }\left(r_{i j} \neq 0\right) .
\end{aligned}
$$


Hasil yang diperoleh dari analisis korelasi antara variabel yang ada pada lampiran 1 menunjukkan bahwa semua variabel memiliki hubungan antar variabel ( terima $H_{1}$ ), dimana nilai $r_{i j} \neq 0$ sehingga dapat dilanjutkan dengan Analisis komponen utama.

\subsection{Analisis Komponen Utama}

Setelah data dianalisis korelasi dilanjutkan dengan membuat komponen utama untuk menentukan berapa banyak faktor yang dapat dibentuk. pertama menentukan nilai eigen dan vektor eigen dari data variabel awal dengan menggunakan IBM SPSS, dalam hal ini nilai eigen merupakan varians dari komponen utama dan vektor eigen merupakan koefisien dari komponen utama. Hasil proporsi dari nilai eigen dituangkan dalam tabel 1.

Tabel 1. Varians nilai eigen

\begin{tabular}{|c|c|c|c|}
\hline KU & $\begin{array}{c}\text { Nilai } \\
\text { Eigen }\end{array}$ & $\begin{array}{c}\text { Proporsi } \\
(\%)\end{array}$ & Kumulatif(\%) \\
\hline 1 & 5,218 & 31,065 & 31,065 \\
\hline 2 & 3,130 & 18,410 & 49,475 \\
\hline 3 & 2,798 & 16,461 & 65,936 \\
\hline 4 & 1,520 & 8,944 & 74,880 \\
\hline 5 & 1,381 & 8,122 & 83,002 \\
\hline 6 & 0,803 & 4,725 & 87,727 \\
\hline 7 & 0,562 & 3,304 & 91,032 \\
\hline 8 & 0,420 & 2,472 & 93,503 \\
\hline 9 & 0,316 & 1,859 & 95,363 \\
\hline 10 & 0,257 & 1,513 & 96,876 \\
\hline 11 & 0,145 & 0,851 & 97,726 \\
\hline 12 & 0,121 & 0,710 & 98,437 \\
\hline 13 & 0,104 & 0,613 & 99,050 \\
\hline 14 & 0,083 & 0,491 & 99,541 \\
\hline 15 & 0,054 & 0,316 & 99,856 \\
\hline 16 & 0,024 & 0,144 & 100,000 \\
\hline 17 & $7,164 \mathrm{E}-6$ & $4,214 \mathrm{E}-5$ & 100,000 \\
\hline
\end{tabular}

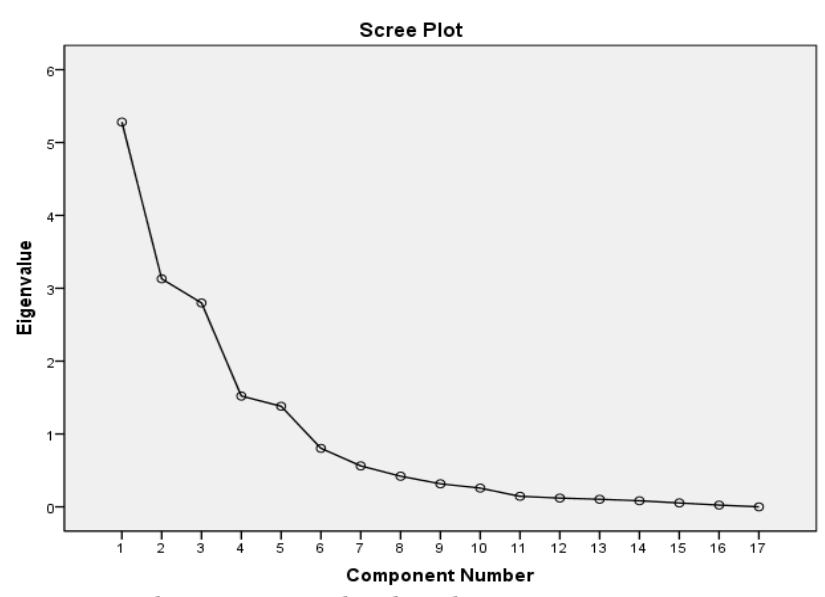

Gambar 1. Scree Plot data komponen utama.

Pada tabel 1 dan gambar 1 dapat dilihat nilai eigen dari komponen utama pertama $\left(K U_{1}\right)$ sampai dengan nilai eigen komponen utama ke tujuh belas $\left(K U_{17}\right)$ yang semakin kecil yaitu dari kiri atas ke kanan bawah. Kemudian pada nilai vektor eigen yang merupakan koefisien dari komponen utama dapat dilihat pada tabel 1 , bahwa ada 17 komponen utama yang terbentuk dari data variabel asal dengan proporsi yang berbeda-beda tetapi hanya 13 komponen utama yang dapat menjelaskan data variabel asal, karena hasil dari analisis menunjukkan bahwa $K U_{14}, K U_{15}, K U_{16}$, dan $K U_{17}$ memiliki nilai eigen dibawah $0,1 \%$.

Dalam tabel 1 memperlihatkan nilai eigen dan proporsi yang terbentuk dari komponen utama yang terlihat bahwa $K U_{1}$ dapat mewakili $31,065 \%$ data dari variabel asal, $K U_{2}$ dapat mewakili $18,410 \%$ data dari variabel asal, $K U_{3}$ dapat mewakili 16,461 data dari variabel asal, $\mathrm{KU}_{4}$ dapat mewakili $8,944 \%$ data dari variabel asal, $K U_{5}$ dapat mewakili $8,112 \%$ data dari variabel asal, $K U_{6}$ dapat mewakili $4,725 \%$ data dari variabel asal, $\mathrm{KU}_{7}$ dapat mewakili $3,304 \%$ data dari variabel asal, $K U_{8}$ dapat mewakili $2,472 \%$ data dari variabel asal, $K U_{9}$ dapat mewakili $1,859 \%$ data dari variabel asal, $K U_{10}$ dapat mewakili $1,513 \%$ data dari variabel asal, $K U_{11}$ dapat mewakili $0,851 \%$ data dari variabel asal, $K U_{12}$ dapat mewakili 0,710 data dari variabel asal, $K U_{13}$ dapat mewakili o,613\% data dari variabel asal, $K U_{14}, K U_{15}, K U_{16}$, dan $K U_{17}$ mewakili data dibawah 0,5\% yang artinya $K U_{14}, K U_{15}, K U_{16}$, dan $K U_{17}$ kurang dapat mewakili data dari variabel asal.

Koefisien pada tiap komponen utama yang tebentuk merupakan matriks vektor eigen dari 33 desa dan kelurahan di Kota Kotamobagu yaitu, Kopandakan I, Bungko, Tabang, Poyowa Besar I, Poyowa Besar II, Pobundayan, Motoboi Kecil, Mongondow, Poyowa Kecil, Matali, Motoboi Besar, Kobo Kecil, Moyag, Kobo Besar, Tumubuy, Sinindian, Kotobangon, Moyag Tampoan, Moyag Todulan, Mongkonai, Molinow, Mogolaing, Gogagoman, Kotamobagu, Mongkonai Barat, Upai, Genggulang, Biga, Sia, Pontodon, Bilalang I, Bilalang II, dan Pontodon Timur. Selanjutnya diambil beberapa komponen utama yang bisa mewakili data dari variabel asal. Jika yang diambil satu komponen utama pertama saja dengan proporsi nilai eigen hanya $31,065 \%$ sehingga dianggap belum dapat menggambarkan keragaman total, tetapi bila diakumulasikan proporsi dari $K U_{1}, K U_{2}$, dan $K U_{3}$ maka menghasilkan proporsi sebesar $65,936 \%$ yang bisa mewakili dari total variabilitasnya.

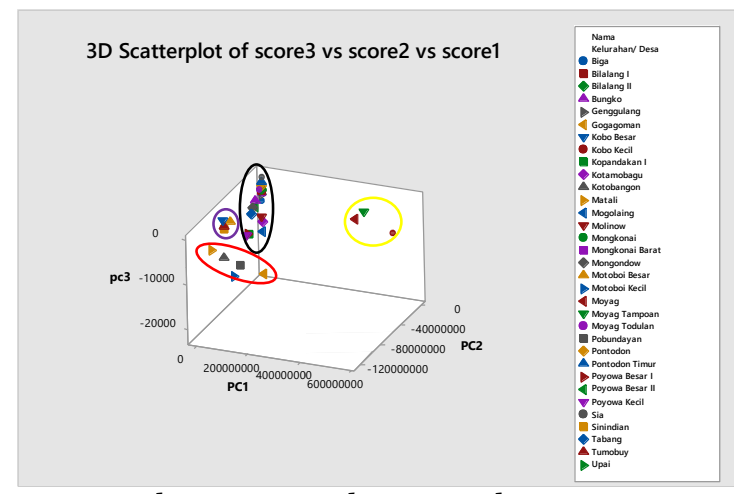

Gambar 2. Scree Plot antar 3 koponen utama.

Pada gambar 2 dapat dilihat bahwa tingkat kesejahteraan tiap desa rata-rata hampir sama, dalam gambar tersebut bisa dilihat menjadi 4 kelompok yang tingkat kesejahteraan berdasarkan variabel sosial ekonomi. Pada lingkar berwarna hitam dan ungu tingkat kesejahteraannya lebih unggul ke $\mathrm{PC}_{3}$, sedangkan untuk lingkar merah tingkat kesejahteraannya lebih unggul ke $\mathrm{PC} 2$, dan untuk lingkar kuning tingkat kesejahteraannya lebih unggul ke PC1. 


\subsection{Analisis Faktor}

Setelah dianalisis komponen utama dan telah diketahui 3 komponen utama yaitu $K U_{1}, K U_{2}$, dan $K U_{3}$ yang akan dipakai, maka akan dilanjutkan dengan analisis faktor untuk mengetahui variabel apa saja yang mempengaruhi 3 komponen utama tersebut. Hasilnya dituangkan dalam tabel 2.

Tabel 2. Matriks komponen utama

\begin{tabular}{|c|c|c|c|}
\hline Variabel & $K U_{1}$ & $K U_{2}$ & $K U_{3}$ \\
\hline$X_{1}$ & 0,148 & $-0,028$ & $-0,189$ \\
\hline$X_{2}$ & 0,051 & 0,920 & 0,117 \\
\hline$X_{3}$ & $-0,059$ & 0,352 & 0,030 \\
\hline$X_{4}$ & 0,890 & 0,056 & $-0,188$ \\
\hline$X_{5}$ & 0,033 & 0,959 & $-0,127$ \\
\hline$X_{6}$ & 0,857 & $-0,076$ & $-0,136$ \\
\hline$X_{7}$ & 0,033 & 0,959 & $-0,128$ \\
\hline$X_{8}$ & 0,887 & 0,038 & $-0,292$ \\
\hline$X_{9}$ & 0,804 & 0,100 & 0,337 \\
\hline$X_{10}$ & 0,678 & 0,033 & 0,202 \\
\hline$X_{11}$ & 0,046 & 0,184 & $-0,091$ \\
\hline$X_{12}$ & 0,202 & $-0,185$ & 0,206 \\
\hline$X_{13}$ & $-0,589$ & 0,004 & 0,193 \\
\hline$X_{14}$ & $-0,057$ & $-0,050$ & 0,193 \\
\hline$X_{15}$ & $-0,054$ & $-0,070$ & 0,846 \\
\hline$X_{16}$ & 0,779 & 0,059 & 0,391 \\
\hline$X_{17}$ & 0,195 & $-0,013$ & 0,603 \\
\hline
\end{tabular}

Dari tabel 2 Matriks komponen utama diatas, jika diturunkan dalam bentuk persamaan matematis adalah sebagai berikut :

$$
\begin{aligned}
K U_{1}=0,148 X_{1}+ & 0,051 X_{2}-0,059 X_{3}+0,890 X_{4} \\
& +0,033 X_{5}+0,857 X_{6}+0,033 X_{7} \\
& +0,887 X_{8}+0,804 X_{9}+0,678 X_{10} \\
& +0,046 X_{11}+0,202 X_{12}-0,589 X_{13} \\
& -0,057 X_{14}-0,054 X_{15}+0,779 X_{16} \\
& +0,195 X_{17} \\
K U_{2}=-0,028 X_{1}+ & 0,920 X_{2}+0,352 X_{3}+0,056 X_{4} \\
& +0,959 X_{5}-0,076 X_{6}+0,959 X_{7} \\
& +0,038 X_{8}+0,100 X_{9}+0,033 X_{10} \\
& +0,184 X_{11}-0,185 X_{12}+0,004 X_{13} \\
& -0,050 X_{14}-0,070 X_{15}+0,059 X_{16} \\
& -0,013 X_{17} \\
K U_{3}=-0,189 X_{1}+ & 0,117 X_{2}+0,030 X_{3}-0,188 X_{4} \\
& -0,127 X_{5}-0,136 X_{6}-0,128 X_{7} \\
& -0,292 X_{8}+0,337 X_{9}+0,202 X_{10} \\
& -0,091 X_{11}+0,206 X_{12}+0,193 X_{13} \\
& +0,193 X_{14}+0,846 X_{15}+0,391 X_{16} \\
& +0,603 X_{17}
\end{aligned}
$$

Pada tabel 2 dan dalam bentuk persamaan matematis dapat dilihat bahwa pada $K U_{1}$ variabel yang memberikan korelasi diatas 0,5 adalah $X_{4}$ sebesar 0,890, $X_{8}$ sebesar 0,887, $X_{6}$ sebesar 0,857, $X_{9}$ sebesar $0,804, \quad, X_{16}$ sebesar $0,779 X_{10}$ sebesar $0,678, X_{13}$ sebesar -0,589, pada $K U_{2}$ variabel yang memberikan korelasi diatas 0,5 adalah $X_{5}$ sebesar 0,959, $X_{7}$ sebesar 0,959, $X_{2}$ sebesar 0,920 , pada $K U_{3}$ variabel yang memberikan korelasi diatas 0,5 adalah $X_{15}$ sebesar o,846, dan $X_{17}$ sebesar o,6o3.

Tabel 3. Variabel 3 komponen utama

\begin{tabular}{|c|c|c|}
\hline$K U_{1}$ & $K U_{2}$ & $K U_{3}$ \\
\hline$X_{4}:$ Jumlah \\
Lembaga Adat & $\begin{array}{c}X_{2}: \text { Jumlah RT } \\
\text { per kelurahan } \\
\text { atau desa }\end{array}$ & $\begin{array}{c}X_{15}: \text { Jumlah } \\
\text { Industri } \\
\text { Lainnya }\end{array}$ \\
\hline $\begin{array}{c}X_{8}: \text { Jumlah } \\
\text { Rumah Tangga } \\
\text { RT) per kepala } \\
\text { keluarga }\end{array}$ & $\begin{array}{c}X_{5}: \text { Jumlah } \\
\text { Penduduk } \\
\text { Tahun 2017 }\end{array}$ & $\begin{array}{c}X_{17}: \text { Jumlah } \\
\text { PBB neto }\end{array}$ \\
\hline$X_{6}:$ Laju & $X_{7}:$ Jumlah & \\
Pertumbuhan & Total & \\
Penduduk & Penduduk & \\
Pertahun (\%) & & \\
\hline$X_{9}:$ Jumlah & & \\
Taman Kanak- & & \\
Kanak (TK) & & \\
\hline$X_{10}:$ Jumlah & & \\
Sekolah Dasar & & \\
(SD) & & \\
\hline$X_{13}:$ Jumlah & & \\
Tempat & & \\
Peribadatan & & \\
\hline$X_{16}:$ Jumlah & & \\
PBB Bruto & & \\
\hline
\end{tabular}

Dari hasil Analisis Faktor diatas dapat diketahui variabel apa saja yang mempengaruhi tingkat kesejahteraan pada 3 komponen utama. Pada tabel 3 memperlihatkan bahwa pada $K U_{1}$ variabel yang paling mempengaruhi adalah $\left(X_{4}\right)$ Jumlah Lembaga Adat, $\left(X_{6}\right)$ Laju Perumbuhan Penduduk pertahun (\%), $\left(X_{8}\right)$ Jumlah Rumah Tangga (RT) per Kepala Keluarga, $\left(X_{9}\right)$ Jumlah Taman Kanak-Kanak (TK), $\left(X_{10}\right)$ Jumlah Sekoah Dasar (SD), $\left(X_{13}\right)$ Jumlah Tempat Peribadatan, $\left(X_{16}\right)$ Jumlah PBB Bruto, yang akan paling menunjang tingkat kesejahteraan sosial ekonomi setiap desa, pada $\mathrm{KU}_{2}$ variabel $\left(X_{2}\right)$ Jumlah RT per Desa atau Kelurahan, $\left(X_{5}\right)$ Jumlah Penduduk Tahun 2017, $\left(X_{7}\right)$ Jumlah Total Penduduk, adalah yang paling memberikan pengaruh, dan pada $K U_{3}$ variabel yang paling mempengaruhi adalah $\left(X_{15}\right)$ Jumlah Industri Lainnya, dan $\left(X_{17}\right)$ Jumlah PBB neto sedangkan untuk variable $\left(X_{1}\right)$ Luas, $\left(X_{3}\right)$ Tipe Desa, $\left(X_{11}\right)$ Jumlah Sekolah Menengah Pertama, $\left(X_{12}\right)$ Jumlah Puskesmas, $\left(X_{14}\right)$ Jumlah Industri Makanan, sudah tidak terpakai lagi atau tereduksi dengan sendirinya karena memberikan korelasi dibawah 0,5 pada setiap komponen utama yang ada.

\section{Kesimpulan dan Saran}

\subsection{Kesimpulan}

1. Analisis Komponen Utama dari 33 desa dan kelurahan dengan 17 variabelnya terbentuk 3 komponen utama yaitu $K U_{1}, K U_{2}$, dan $K U_{3}$ yang mewakili $65,936 \%$ variabilitasnya. dapat dilihat dari Plot Multivariate Analisis komponen utama pada hasil penelitian bahwa setiap desa dan kelurahan mempunyai letak titik tingkat kesejateraan yang rata-rata sama. Karena tingkat kesejahteraan setiap desa dan keluarahan ada yang sangat mirip sehingga ada titik-titiknya yang saling tumpang tindih.

2. variabel yang mempengaruhi tingkat kemiripan kesejahteraan pada 3 komponen utama.yaitu pada $K U_{1}$ variabel yang paling mempengaruhi adalah 
Jumlah Lembaga Adat $\left(X_{4}\right)$, Laju Pertumbuhan Penduduk Per Tahun $\left(X_{6}\right)$, Jumlah Rumah Tangga (RT) per Kepala Keluarga $\left(X_{8}\right)$, Jumlah Taman Kanak-kanak $\left(X_{9}\right)$, Jumlah Sekolah Dasar $\left(X_{10}\right)$, Jumlah Tempat Peribadatan $\left(X_{13}\right)$, Jumlah PBB Bruto $\left(X_{16}\right)$, pada $K U_{2}$ variabel yang paling mempengaruhi adalah Jumlah RT per Desa atau Kelurahan $\left(X_{2}\right)$, Jumlah Penduduk Tahun 2017 $\left(X_{5}\right)$, Jumlah Total Penduduk $\left(X_{7}\right)$, pada $K U_{3}$ variabel yang paling mempengaruhi adalah Jumlah Industri Lainnya $\left(X_{15}\right)$,Jumlah PBB Neto $\left(X_{17}\right)$.

\subsection{Saran}

Bagi peneliti yang ingin melanjutkan penelitian ini dengan metode yang sama disarankan untuk menggunakan data variabel yang lebih banyak lagi, agar dapat mengetahui tingkat kesejahteraan setiap desa dan kelurahan lebih detail lagi.

\section{REFERENSI}

[1] Abudruachman, S. H., H. Komalig, N. Nainggolan. 2014 . Penggunaan Analisis Komponen utama Dalam Penggabungan Data Peubah Ganda pada Kasus Produksi Pertanian dan Perkebunan di Wilayah Bolaang Mongondow Tahun 2008. FMIPA UNSRAT,Manado. Jurnal de cartesian. 3(2):1-7

[2] Anand, S. dan Amartya Sen. 1993. Human Development Index: Methodology and Measurement.Human Development Report Office, Occasional Paper No. 12, United Nations Development Programme, New York.

[3] Conyers, Diana. 1991. Perencanaan Sosial di Dunia Ketiga. Suatu Pengantar (terj. Susetiawan). UGM Pers, Yogyakarta.

[4] Demarest, E.J., et al. 1993. Review of research on achieving the nation's readiness goal, U.S. Department of Education, Washington, DC.

[5] Helen N. 2015 . Analisis Korelasi Komponen Sosial Dan Ekonomi Masyarakat Pesisir Dalam Pemanfaatan Ekosistem Mangrove Di Teluk Kotania,Kabupaten Seram Bagian Barat,Provinsi Maluku. Jurnal Insei. 2(4):1-2

[6] Iriyani, D., dan Nugrahai, P., 2016 . Karakterisasi Faktor Sosial Ekonomi Berdasarkan Analisis Komponen Principal pada Pertanian Periurban Kota Surabaya. Jurnal Rekayasa. 1(9): 18-41

[7] Johnson, R. A. and D. W. Wichern. 2002. Applied Multivariate Statistical Analysis. Prentice- Hall, Englewood Cliffs, New Jersey.

[8] Morrison, D. F. 1990. Multivariate Statistical Methode $3^{\text {rd }}$. Mc Graw Hill Publishing Company, New York.

[9] Pratiwi, D. F. 2017 . Meta-Analisis Jumlah Spesies Tumbuhan Obat Yang Digunakan Berdasarkan Karakteristik Faktor Sosial Ekonomi, Lingkungan, Dan Geografis Di 40 Desa Indonesia .[Tesis] . FMIPA IPB, Bogor.

[10] Rencher, A.C. 2001. Methods of Multivariate Analysis. Second Edition. A Wiley-Interscience
Publication, New York

[11] Santoso E.B., Widya, dan Rini Ratna. 2014. Gerakan Pertanian Perkotaan Dalam Mendukung Kemandirian Masyarakat Di Kota Surabaya. Seminar Nasional Cities 2014, Surabaya : 5 November 2014. Hal.1-11.

[12] Siswadi, dan B. Suharjo.1997. Analisis Eksplorasi Data Peubah Ganda.FMIPA IPB, Bogor.

[13] Suryanto. 1988. Metode Statistika Multivariat. Departemen Pendidikan dan Kebudayaan, Jakarta.

[14] Todaro, P. Michael. 2000. Pembangunan Ekonomi di Dunia Ketiga. Edisi Ketujuh. Erlangga, Jakarta.

[15] Yustika, Erani A. 2002. Pembangunan dan Krisis, Memetakan Perekonomian Indonesia. PT Gramedia Widiasarana Indonesia, Jakarta.

Siti Regina O. Malah (rhena2222@gmail.com)

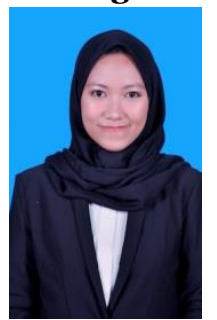
Lahir di Kotamobagu, Sulawesi Utara pada tanggal o1 Oktober 1997. Menempuh pendidikan tinggi Jurusan Matematika, FMIPA, Universitas Sam Ratulangi Manado. Tahun 2018 adalah tahun terakhir ia menempuh studi. Makalah ini merupakan hasil penelitian skripsinya yang dipublikasikan.

Charles E. Mongi (charlesmongi@unsrat.ac.id)

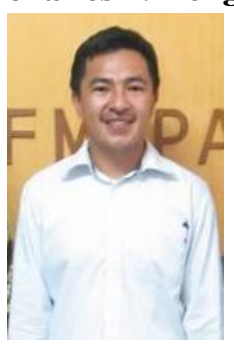

Lahir di Tondano, 4 Januari 1984. Pada tahun 2006 memperoleh gelar Sarjana Matematika di Universitas Sam Ratulangi, Manado. Melanjutkan di Institut Pertanian Bogor tahun 2011 dan mendapatkan Gelar Magister bidang Statistika Matematika pada tahun 2014. Menjadi pengajar di jurusan Matematika, Fakultas Matematika dan Ilmu Pengetahuan Alam, Universitas Sam Ratulangi Manado pada tahun 2010.

Hanny A. H. Komalig (hanoyo7@yahoo.com)

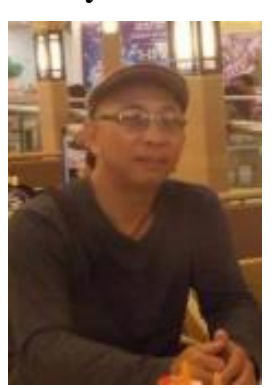

Pada tahun 1990, memperoleh gelar Insinyur di Fakultas Pertanian, Universitas Sam Ratulangi Manado. Kemudian ia mengikuti Basic Siences Bridging Program bidang Matematika di Institud Teknologi Bandung pada tahun 1992 selama 2 tahun. Selanjutnya memperoleh gelar Magister Sains bidang Statistika di Institud Pertanian Bogor tahun 1998. Dan pada tahun 2008 memperoleh gelar Doktor di Universitas Airlangga Surabaya untuk bidang Matematika Modeling. Menjadi dosen di departemen Matematika, FMIPA, Universitas Sam Ratulangi pada tahun 2000 sampai sekarang. Bidang keahlian yang ditekuni yaitu diantaranya; Statistika Multivariat Nonlinier dan Reduksi Dimensi. 